<総 説 $>$

\title{
文化財の保存科学的処理 \\ Conservation treatment of Cultural Property
}

川本 耕三*

Kozo KAWAMOTO

\section{1.はじめに}

現代に通じる文化財保存は，大正時代に岡倉天心が提唱 した法隆寺金堂壁画の保存調査にはじまるといわれる。こ の調查では, 壁画の膠が劣化して剥落しかけた顔料を熱分 解して溶剤に溶け易くした琥珀のアルコール・エーテル溶 液で止める実験 ${ }^{1)}$ をはじめとして，膠やでんぷん糊など の伝統的天然材料やアクリル樹脂などの新規合成材料によ る種々の方法を用いた保存科学的処理の検討が行われた。

以来, 数千年間土中に埋納された出土品, 神社や仏閣・ 民家などに伝わる伝世品に対して, 剥離・破断部の接着や 欠損部の補填等が行われた。また, 素材として見ると, 金 属や石材等の無機物や，木材や紙・布・プラスチック・ゴ ムなどの有機物が, 接着剤により数多く修復された。これ らの保存科学的処理は, 岡倉天心の「現状維持修理」やヴェ ニス憲章 ${ }^{2)}$ 等をはじめとする理念に則って行われている。

\section{2. 文化財の保存科学的処理における接着剤の使用}

文化勛の保存科学的処理に特によく用いられるのは, 無 溶剤で硬化前後の体積变化が少ないエポキシ樹脂や, 保存 処理後に溶剤で取り除くことができる熱可塑性のアクリル 樹脂等である。現在では工業分野で開発され実績のある製 品から選択されることが多い。

まず，文化財の保存科学的処理にどのような接着剤が用 いられたか述べる。

\section{1 彩色壁画等の剥落止め}

法隆寺金堂壁画の保存修復を検討する過程で，昭和 17 年（1942）に奈良県霊山寺三重塔（鎌倉時代）の内部建築 彩色の剥落止めにアクリル樹脂が初めて用いられた ${ }^{1)}$ 。

$*$ 財団法人 元興寺文化財研究所 奈良県生駒市元町 2-14-8 干 630-0257

Gangoji Institute for Cultural Property

2-14-8, Motomachi, Ikoma-city, Nara, 630-0257, Japan
その後はポリビニルアルコールやエマルジョン系アクリ ル樹脂, ポリビニルブチラール等が用いられた。近年は合 成樹脂と膠や六の等の伝統材料が併用されている。

\section{2 建造物等の欠損した木材への補填}

昭和 43 年（1968）に元興寺極楽坊国宝五重小塔（奈良 時代, 写真 1）の解体修理で木材の欠損部にフェノール樹

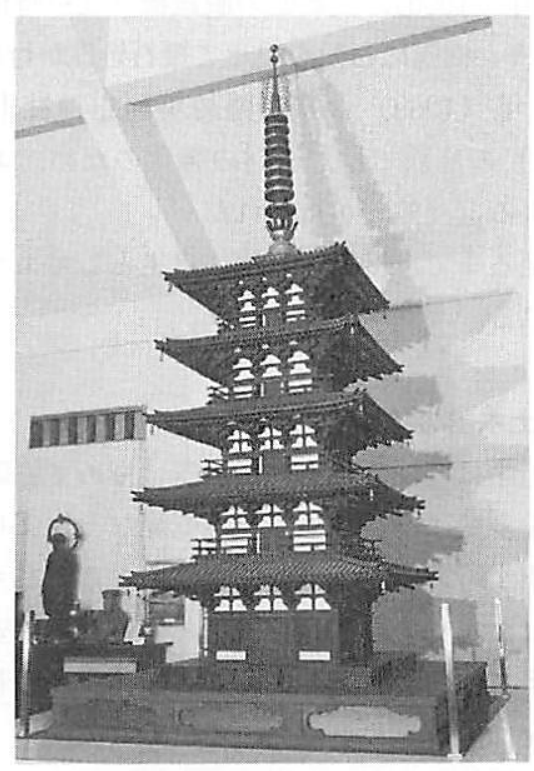

写真 1 元興寺極楽坊国宝五重小塔

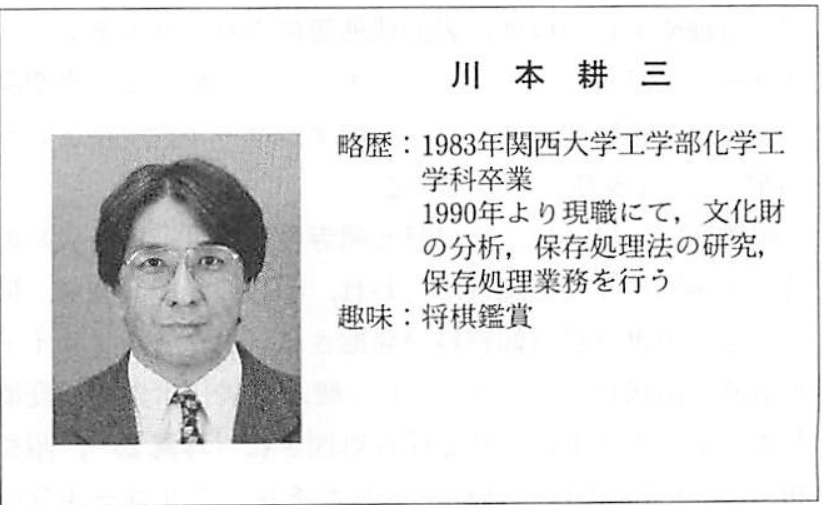


脂マイクロバルーンを混入したエポキシ樹脂（アラルダイ

トSV426）が充填された ${ }^{3)}$ 。

現在もフェノール樹脂やガラスのマイクロバルーンをフィ ラーとして混入したエポキシ樹脂がよく用いられている。

\section{3 土器・埴輪等の接着と補填}

土器や埴輪は発掘現場で記録のため応急的に組み上げら れる事が多く，しばしば身近な製品から保存処理材料が選 ばれてきた。

接着にはセルロース系樹脂 (セメダイン C 等), 酢酸ビ ニル系樹脂 (コニシボンド木工用等), エポキシ樹脂（セ メダインハイスーパー等) がよく用いられる。補填には明 治時代から石高がよく用いられてきたが, 近年では石亭に 樹脂などを混合したモデライトなどの改良石亳やフィラー を混入したエポキシ樹脂も用いられる

また, 土器にアクリル樹脂を含浸や塗布をするなど，接 合部分を強化したうえで，接着・補填が行われる場合むあ る。

\section{4 石材等の接着と補填}

昭和 35 年（1960）, 長崎県の眼鏡橋（江戸時代）の修理 では, エポキシ樹脂に石粉を混ぜて擬石処理が行われた ${ }^{1,5)}$ 。

昭和 44 年（1969）の奈良県於美阿志神社十三重石塔 （平安時代）の修理では, 石材の強化のため, エチルシリ ケートによる含浸処理が行われた ${ }^{1,5)}$ 。

現在に至るまで，接着・充填には主としてエポキシ樹脂 が用いられる。

\section{5 出土木器の接着と補填}

長期間地中に埋納されていた木器は極めて脆弱なものが 多く水分を多量に含むため, 自然乾燥などにより水分を除 去すると出土時の形状を維持できなくなり著しく収縮・変 形する。したがって, 水分を展示・保管環境で安定な物質 に置き換えて強化する必要がある。強化後，接着・補填等 による復元作業が行われる。

これまで種々の物質を含浸して出土木器を強化する試み が行われてきたが, 現在, 元興寺文化財研究所では出土木 器の樹種や劣化の程度, 表面状態等によりポリエチレング リコール含浸法, アルコールーキシレンー樹脂法, 真空凍 結乾燥法, 脂肪酸エステル法, 糖アルコール含浸法という 5 種類の方法を使い分けている。

昭和 36 年 (1961), 奈良県元興寺極楽坊（奈良時代）の 防災工事に伴う発掘調查が行われ, 十数万点の五輪塔, 柿 経などの中世庶民信仰資料が発掘され，アクリルアマイド 水溶液浸漬後に L-アスコルビン酸, 過酸化水素水へ浸漬 してレドックス重合させる保存処理され (写真 2) ${ }^{6)}$, 昭和 40 年（1965）には, 柿経がポリエチレングリコール含浸

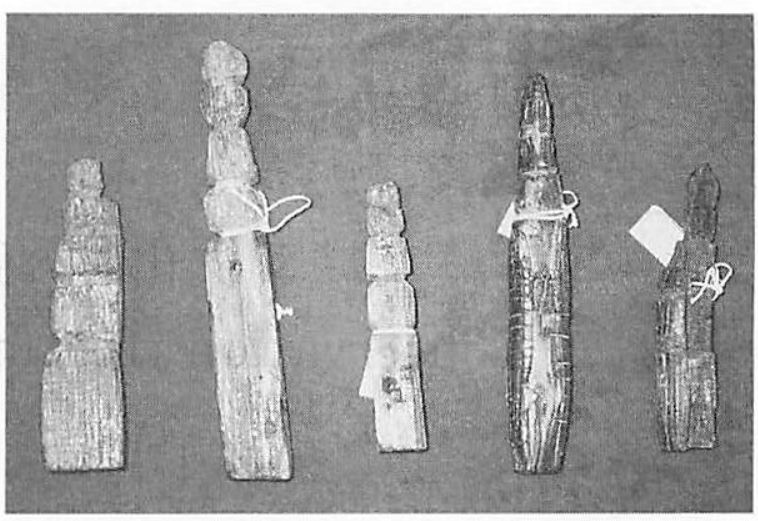

写真 2 元興寺極楽坊出土五輪塔（保存処理後）

法により処理された ${ }^{7)}$ 。

現在に至るまで，接着にはエポキシ樹脂とシアノアクリ レート系接着剤, 補填にはフィラーを混入したエポキシ樹 脂が用いられている。

\section{6 出土金属器の接着と補填}

出土木器の保存科学的処理の課題がその形状を維持する ことにあるのに対し, 出土金属器の場合は劣化（錆化）の 進行を極力押し留めることにある。したがって, 劣化の内 部要因を取り除き，外部要因を遮断する必要がある。

出土鉄製品を例にとると, 現在, 元興寺文化財研究所で はセスキ炭酸ナトリウム水溶液に浸漬することによる脱塩 処理（塩化物イオンや硫酸イオン等の劣化要因を液中に溶 出させて除去する処理）上，アクリル系樹脂による含浸強 化処理が行われている。接着や補填にはエポキシ樹脂やシ アノアクリレート系接着剤が用いられている。

1950 年代までは，加熱した油やパラフィン（石油ワッ クス), ロウに鉄器を浸漬し水分除去と含浸強化処理が行 われていた。また，表面にはセルロイドのアセトン溶液が 塗布される場合もあった。

現在に通じる保存科学的処理は, 昭和 43-44 年（196869）に行われた日光男体山山頂祭祀遺跡出土鉄器（奈良〜 江戸時代）の処理 ${ }^{8)}$ で, アクリル樹脂による含浸処理の 後, 破断簓所がエポキシ樹脂により接着された。

その他, 文化財保存や用いられてきた合成樹脂, 接着剂 の歴史については文献 $5,9,10)$ を参考にされたい。

\section{3. 接着剤と保存修復材料}

文化財の保存修復には種々の薬剤が使われている。多く は工業分野での奏績があるものの, 保存修復独自の方法や 組み合わせにより用いた場合に材料の劣化を促進するなど の悪影響が表れることがある。

ここではその一例として, 出土木器の保存処理に用い られるエポキシ樹脂（主剂：ビスフェノール $\mathrm{A}$ 型エポキ シ樹脂, 硬化剤：ポリチオール）が, 5 種類の保存処理法 
で用いられる保存処理材料との相互作用によって起こる少 化 (性能低下) を試験片での力学的な実験等により考察し た。

\section{1 出土木器保存処理法}

まず, 出土木器の 5 種類の保存処理法とその特徵につい て簡単に述べる。

3.1 .1 処理法 I ポリエチレングリコール含浸法 (PEG 法) ${ }^{11,12)}$

出土木器の代表的な水系処理法で, 主として平均分子量 が 3 千余で融点が $55^{\circ} \mathrm{C}$ 前後の PEG 4000 を用い, 出土木 器を浸漬する水溶液の濃度を段階的に上昇させて, 出土木 器が持つ水分を PEG に置換する方法である。

これまで, 最む多くの出土木器がこの方法により処理さ れた, 汎用性のある処理法である。

3.1 .2 処理法 II アルコールーキシレンー樹脂法 (AXR 法) ${ }^{13)}$

含浸樹脂が非水系であるため，処理は 3 段階になる。(1) 遺物中の水分をエタノールに置換, (2)さらにキシレンに 置換, (3) ロジンやダンマルガムなどの天然樹脂溶液（濃 度 $30 \%$ のキンン溶液）に含浸後，溶剂を揮発させる。

天然樹脂は粘度が高いため含浸速度は遅いが, 処理した 木器は可撓性のある仕上がりになる。木簡や曲物など厚み の小さい出土木器の処理に適している。

\subsection{3 処理法III 真空凍結乾燥法 (FD 法) ${ }^{14)}$}

PEG 法では, 含浸液の濃度が $60 \%$ 前後のときに遺物が 変形・収縮を起こすことがある。この現象を回避するため, FD 法では遺物内の水分を $40 \%$ 程度まで PEG に置換した 後, 真空凍結乾燥によって残りの水分を除去する。

PEG 法に比べて出土木器内に充填される PEGの量が少 ないため, 強度は大きくならない。比較的劣化していない 針葉樹で作られた木器や漆製品の処理に向いている。

3.1.4 処理法IV 脂肪酸エステル法 (HSM 法) ${ }^{15,16)}$

アルコールなどに溶ける薬阂を使用するため, 処理法 II （AXR 法）に比べて処理を 1 工程省略できる。(1) 遺物中 の水分をエタノールに置換, (2) 12 -ヒドロキシステアリン 酸メチル（融点約 $56^{\circ} \mathrm{C}$ ）溶融液に浸漬して, エタノール を揮発, 除去する。

木器の表面にある細かい文様や痕跡を損なわずに処理す ることができる。薬剤が木器表面で白粉状に再結晶する場 合がある。

3.1.5 処理法 V 糖アルコール含浸法 (SA 法) ${ }^{17)}$

処理工程は PEG 法に近い水系処理法だが, PEG と比べ て薬凪の分子量が小さいため拡散速度が速く, より短期間 での処理が可能である。

汎用性のある処理法だが, PEG 法と比べて適用範囲が やや狭く, 含水率の高い広葉樹には適用できない。



図 1 保存処理した出土木材の曲げ強さ試験結果

\section{2 保存処理した出土木材の曲げ強さ}

棒状の出土木器を手に持って観察することを想定した。 まず，出土流木（イタヤカエデ，含水率 * $700 １ 000 \%$ ) から長手方向が織維方向と平行になるように断面 $20 \mathrm{~mm}$ 角正方形, 長さ $100 \mathrm{~mm}$ の直方体木片を切り出し, $\mathrm{I} \sim \mathrm{V}$ の各保存処理法で処理したあのを試験片とした。

この試験片をオートグラフ AGS-H（島津製作所）に 3 点曲げ試験治具を装着し, 支点間距離 $70 \mathrm{~mm}$, 荷重速度 $5 \mathrm{~mm} / \mathrm{min}$ で曲げ強さ試験を行った。

保存処理前の試験片の曲げ強さは数值で表すことができ ないほど小さいが，保存処理することによって図 1 に示し たような曲げ強さとなった。

$※$ 含水率 $(\%)=($ 木材含水分量 $/$ 木材実質重量 $) \times 100$, 含 水率は出土木材の劣化を知るための指標となる。

\section{3 接着した出土木材の曲げ接着強さ}

さらに，3.2 で作製した試験片を出土木器の保存修復に よく用いられるエポキシ樹脂（セメダインハイスーパー） で突合せ接着し（図 2)，JIS K 6856 （接着昘の曲げ接着 強さ試験方法）を参考にして，3.2 と同様の装置を用い, 支点間距離 $70 \mathrm{~mm}$, 荷重速度 $5 \mathrm{~mm} / \mathrm{min}$ で接着強さ試験を 行った（図 3)。その結果を図 4 に示す。

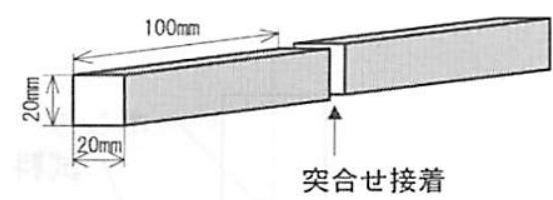

図 2 試験片の接着

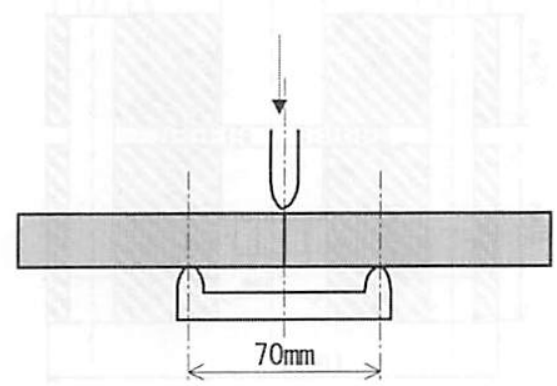

図 3 曲げ接着試験 


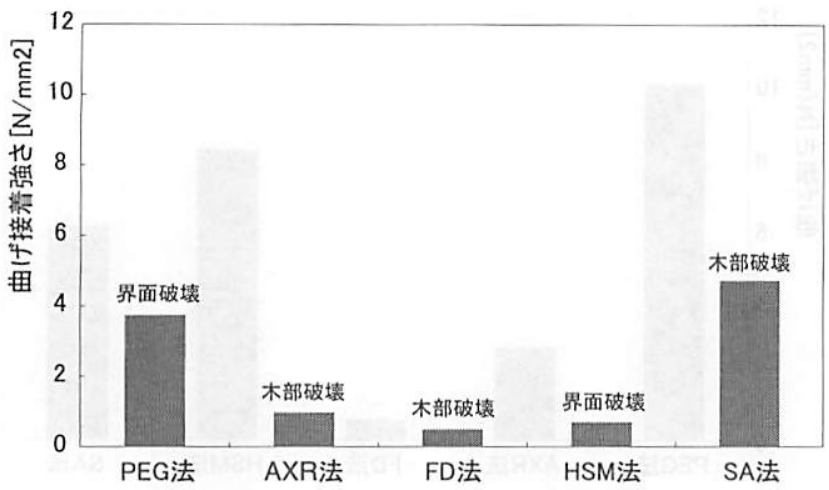

図 4 保存処理した出土木材の曲げ接着強さ試験結果

\section{4 出土木器補填用樹脂の打抜き剪断強さ}

厚さ $1.2 \mathrm{~mm}$ のシート状に硬化させたエポキシ樹脂（セ メダインハイスーパー）を，1辺 $50 \mathrm{~mm}$ の正方形に切断 し，中央に直径 $11 \mathrm{~mm}$ の穴をあけた（図 5)。

次に硬化した接着剤を, 出土木器の保存処理中に遺物内 に残留すると考えられる薬剤である純水，エ夕ノール， キ シレン，また，各処理法の保存処理液である PEG4000 の $30 \%$ 水溶液（PEG 法, FD 法), 天然樹脂の $30 \%$ キシレン 溶液 (AXR 法)，12-ヒドロキシステアリン酸メチル溶融 液（HSM 法)，ラクチトールの $30 \%$ 水溶液（SA 法）に

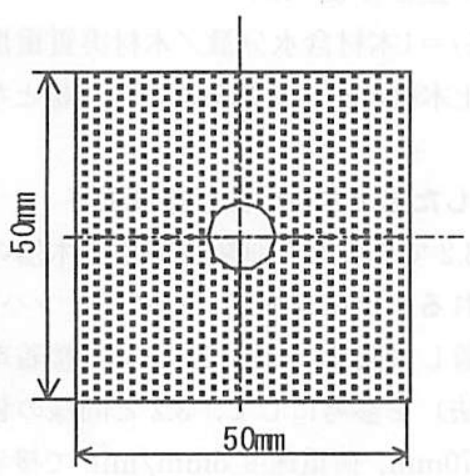

図 5 接着剂試験板



図 6 打ち抜き剪断試験ジク

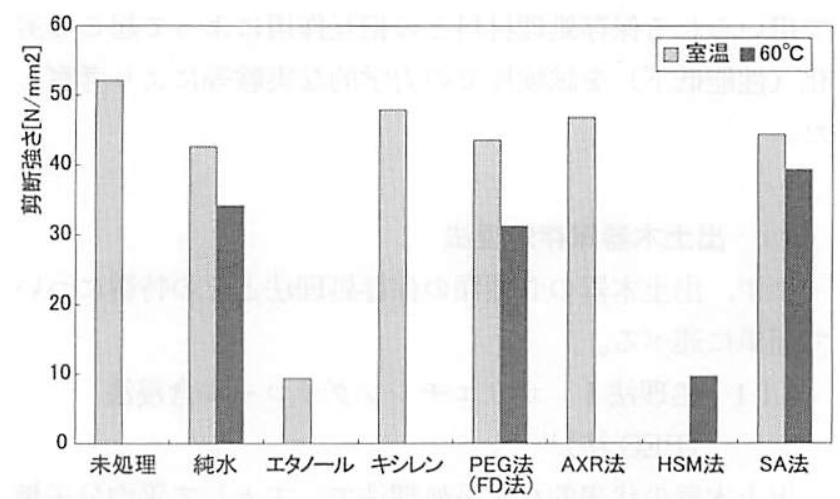

図 7 保存処理液に浸漬処理したエポキシ樹脂硬化シートの 剪断強さ

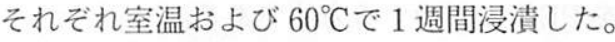

次に, JIS K 7214 （プラスチックの打抜きによる㸘断試 験方法) に準じて，オートグラフ AGS-H $5 \mathrm{KN}$ 型にプラ スチック剪断試験治具（図 6）を装着し，試験速度 $1 \mathrm{~mm} /$ min で打拔き剪断試験を行った。結果を図 7 に示す。

\section{5 力学的実験の考察}

5 種類の保存処理法によって出土木器に付与される強度 は樹種や含水率等の木材の特性によって傾向が異なると思 われるが，この実験では処理法の特性による差が比較的明 瞭に表れたと考えられた。

AXR 法と FD 法は出土木器の空隙に対し薬剂の理論充 填率がそれぞれ 30\%，40\%であるため，木部の強度は小さ くならざるを得ない。実際，この実験では AXR 法と FD 法の曲げ接着強さ試験で，接着部ではなく木部での破壊が 起こった。そのため, 用いる接着剤の接着力を弱くして, 万一の際に新たな破断箇所を増やさないようにする必要が ある。

これに対して, PEG 法と HSM 法では木材強度よりは るかに小さい接着強度しか得ることができなかった。PEG 法は接着部の黄变の様子などから PEG と水分が接着阻害 の要因となっている可能性がある。HSM 法は破断面の接 着剂が軟化し乳白色を呈していたこと, 接着剤に接した木 材表面に 12 -ヒドロキシステアリン酸メチルの白色結晶が 付着していたことから，12-ヒドロキシステアリン酸メチ ルとエタノールが接着阻害の要因となっている可能性があっ た。

保存処理液等に浸漬処理したエポキシ樹脂硬化シートの 剪断強さ試験の結果, HSM 法で処理した試験片の強度は 非常に小さかった。このことからも12-ヒドロキシステア リン酸メチルまたはエタノールが樹脂の強度を低下させて いる可能性が強い。

\section{4. 劣化した接着剤の調查}

保存処理した出土木器を観察すると, 高温高湿状態等に 
置かれた出土木器の接着部が黄变・剥離している例が幾つ かあった（写真 3 )。

力学的試験法により PEG 法と HSM 法で処理された出 土木器のエポキシ樹脂による接着・充填の問題点が明らか になり, 保存処理によって遺物内に浸透した薬阂が溶出し 接着剤に影響を与えたためと考えられた。そのため, 保存 処理を終えて博物館・資料館の収蔵庫等に保管されている 出土木器を調查し, 劣化している接着剤を採取して内層部 の赤外分光分析を行った（図 8,9）。分析装置は SensIR

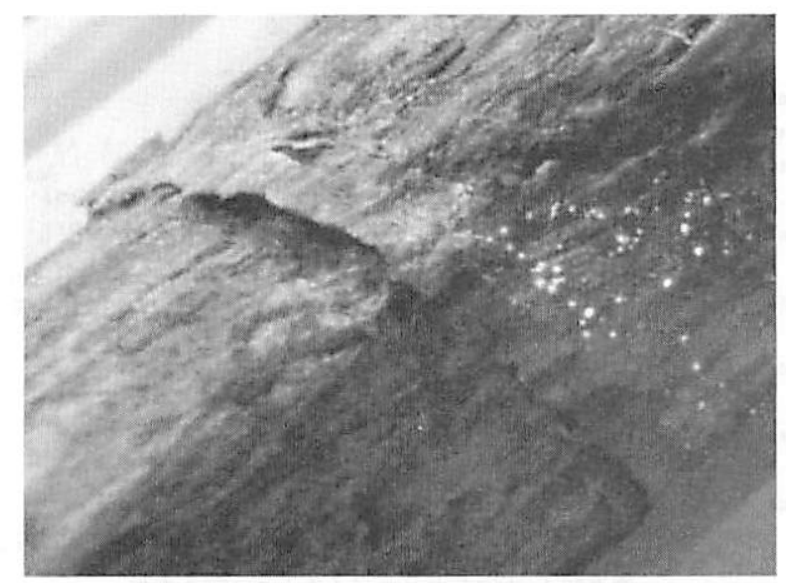

写真 3 PEG 含浸処理した出土木器に補填した エポキシ樹脂の剥離現象

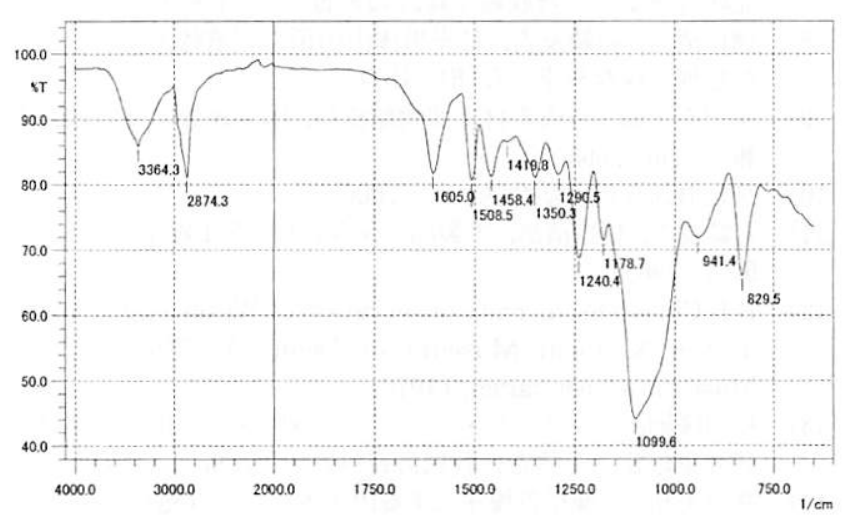

図 8 出土木器 (a) から採取した接着剤の赤外分光分析 スペクトル

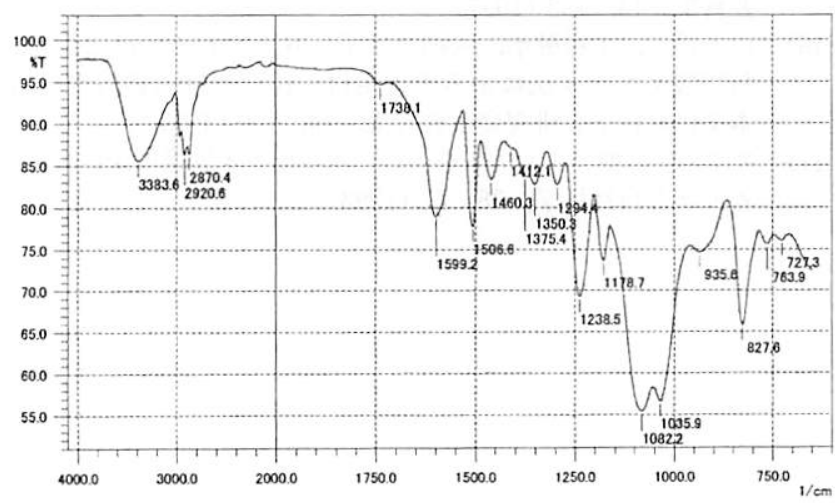

図 9 出土木器 (b) から採取した接着剤の赤外分光分析 スペクトル
Technologies 社の全反射フーリエ変換型赤外分光分析装 置 TravelIR である。

あわせて, 修復記録から保存処理に使用されたことが確 認されているエポキシ系接着剤の硬化物 2 種類と PEG4000, 12-ヒドロキシステアリン酸メチルのスペクトルを測定し, 参考図 1〜4に示した。

\section{出土木器 (a)}

平成 6 年(1994)にPEG 法で処理された。保管環境は比 較的良好であるが, 数年前に除湿装置が故障して高湿度に なったことがある。部分的に補填材が剥離していた。補填 材の赤外分光スペクトルを図 8 に示す。

\section{出土木器 (b)}

平成 8 年 (1996) にHSM 法で処理された。補填材と遺 物の間に隙間が生じていた。補填材の赤外分光スペクトル を図 9 に示す。

2 つのスペクトルは基本的にエポキシ樹脂（修復記録よ り）のものであると思われたが, 出土木器 (a) から採取 した接着剂には PEG が持つエーテル結合 $(\mathrm{C}-\mathrm{O}-\mathrm{C})$ の 対称および逆対称伸縮振動に由来すると思われる 940 , $1100 \mathrm{~cm}^{-1}$ 付近の吸収が見られ（図 8 , 参考図 $1,2,3$ ）, 出土木器 (b) から採取した接着剤には 12 -ヒドロキシス テアリン酸メチルが持つエステル結合 $(>\mathrm{C}=\mathrm{O})$ の伸縮 振動に由来すると思われる $1740 \mathrm{~cm}^{-1}$ 付近の吸収が見られ た（図 9, 参考図 1，2，4）。

そのため, 補填材にそれぞれの保存修復材料 (含浸薬剤) が浸入していたと推测できた。

以上のように, 出土木器の接着や補填では, 木部の強度 が接着部に比べて小さいため観察時に䛊って新たな破断箇 所を生じさせる場合と, 保存処理に用いた薬䬉によって接 着剤の強度が低下して接着部や補填部が外れてしまう場合 が考えられる。

前者は保存処理（薬刱含浸処理）の改良によって木部の 強度を向上させるか, 接着剤の強度（接着力）を木部より あ低下させることによって対処することができる。例えば, 脆弱な紙資料の修復に接着力を弱くした古糊が使われてい る例がある。

後者は油面接着剤等を用いることで, 接着力を向上させ ることができた。

\section{5. おわりに}

文化財の保存科学的処理における接着剤使用の概略と, 近年の出土木器に用いる接着剤の問題点について一例を述 ベた。

今後む保存科学的処理に要求される特性が高度化し, 処 



理すべき文化財の素材や, 対応すべき接着剤等の保存修復 材料の種類は益々増加すると思われる。

文化財は今後永く残すべきものであるから, 各方面の専 門の方々のご協力を仰ぎながらひとつひとつに真摰に対応 し, より良い保存科学的処理を行っていきたい。

\section{参 考 文 献}

1）樋口清治, 回顧：日本における文化財修理への合成樹脂利用 のはじまり，合成素材と博物館資料，国立民族学博物館調 查報告, 36, 53 (2003).

2) http://www.bunka.go.jp/1kokusai/pdf/nara_VC j.pdf.

3）岩崎友吉, 檤口清治, 附録 元興寺極楽坊国宝五重小塔の修 理に使用した合成樹脂について，奈良県文化財保存事務所， 国宝元興寺極楽坊五重小塔修理工事報告苩, 59 (1968).

4) 樋口清治, 今津節生, 出土土器補修用の新材料, 保存科学, 23, 19 (1984).

5）竹之内裕, 川野邀涉, 文化財建造物の修復に用いられた合成 樹脂の变選, 保存科学, 37, 99 (1998).

6）水野正好, 辻村泰園, 南都元興寺極楽坊中世信仰資料包蔵坑 発掘調查概要, 大和文化研究，7(1)，1（1962）.

7）五嶋孝吉，黒田俊子，出土木製品の化学的保存処理について, 元興寺極楽坊総合収蔵庫建設報告荁, 41 (1965).

8）樋口清治, 岩崎友吉, 日光男体山山頂祭祀选跡出土鉄器の保 存処理, 保存科学, 7, 61 (1971)。

9）園田直子編，合成素材と博物館资料，国立民族学博物館調查 報告, 36 (2003).

10）文化財保存修復学会誌，50（2006）.

11）岩崎友吉, 樋口清治, 木製品の保存処理 (第 1 報), 保存科学, 5, 1 (1969).

12) B.B.Christensen, The Conservation of Waterlogged Wood in the National Museum of Denmark, The National Museum, Copenhagen, (1970).

13）松田隆嗣, アルコール・エーテル・樹脂法の応用, 保存科学 研究室紀要, 元興寺仏教民俗資料研究所, 6, 1 (1977).

14）井上美知子, 凍結乾懆法に上る出土木材の保存処理について, 日本文化財科学会研究発表要旨集, 11, 131 (1994).

15）井上美知子，植田值見，川本耕三，脂肪酸エステル法による 出土木材の保存処理実験報告, 日本文化財科学会研究発表 要旨集, 14, 152 (1997).

16）川本耕三，木村健治，大国万希子，井上美知子，植田直見， 脂肪酸エステル法による出土木材の保存処理実験報告, 日 本文化財科学会研究発表要旨集, 14, 150 (1997).

17）今津節生，糖アルコールを用いた水浸出土木製品の保存 (I ), 考古学之自然科学, 28, 77 (1993). 